\title{
The Development of Home Decorative Vetivers Seat Cushion
}

\author{
Rosjana Chandhasa ${ }^{1}$ \\ ${ }^{1}$ Faculty of Industrial Technology, Department of Industrial Design, Suan Sunandha Rajabhat University, \\ Thailand \\ Correspondence: Rosjana Chandhasa, Faculty of Industrial Technology, Department of Industrial Design, Suan \\ Sunandha Rajabhat University, Thailand. Tel: 66-955-181-285. E-mail: rosjana.ch@ssru.ac.th
}

Received: April 28, 2017

doi:10.5539/ass.v13n7p28
Accepted: May 12, $2017 \quad$ Online Published: June 23, 2017

URL: https://doi.org/10.5539/ass.v13n7p28

\begin{abstract}
The aims of this study were: 1) to create a home decorative vetiver seat cushion. 2) To evaluate the received product design (the home decorative vetiver seat cushion), as well as the development process, which covers the research and trial-production improvement by cooperating with vetiver handicraftsmen; furthermore, its procedures consisted of: 1) searching for cultural capital in order to be an inspiration in product design; 2) experimenting to develop the product; 3) summarizing the development procedures; and 4) presenting the result of developed handcraft vetiver sitting-pad model on the following. 1) The identity of handicraftsman community: it should be investigated from the aspect of cultural capital represented by the earthenware shape as well as fabric pattern, 2) the delicate figure and pattern, 3) the usability: the design, size and proportion are suitable and easy to use, 4) the vetiver leaf and production process: the leaves should be tough, strong and hard to be torn; moreover, regarding weaving and finishing the rim, it should be done neatly without visible welded joints, and also 5) the product quality: each part is assembled fixing by leather, inside of the product is attached by cloth as well as filled with leftover fabric. Besides, the sewing should be considerably emphasized the strength to carry weight. In addition, the overall assessment of handcraft vetiver seat cushion model is at a high level.
\end{abstract}

Keywords: Handicraft, Seat Cushion, Vetiver Leaf

\section{Introduction}

"Vetiver": King Rama IX of Thailand advocated the idea of vetiver grass studies in order to prevent soil erosion, as well as to conserve soil moisture. It has also brought other benefits for the greater good from 1991 until now. In 1993, the King ordered various government agencies involved in the propagations to collaborate with the Land Development Department in order to sufficiently produce and distribute vetiver sprouts to the target group. If the vetiver leaf is used as a material in growing, it should have a further study about the adequate numbers of material, if it is pushed forward into an industrial level, because the vetiver is a perennial grass which has many leaves and can grow very fast. Therefore, it was studied in great detail before planting to avoid disadvantages that may affect its main purpose. Using the vetiver grass for other purposes should be prepared in specific cultivated areas in order to suffice for handicraft products. Phayao province is the largest vetiver growing area in the North of Thailand; as a result, it was managed to be investigated and experimented for the growing the vetiver grass under the supervision of the Land Development Department. Similarly, the Department of Industrial Promotion Region 1 also conducted a seminar to acknowledge the vetiver handicraft of the villagers. This inspired the villagers to confederate as a Satri Sahakorn Nikom (Female Agricultural Cooperative), which took the harvested vetiver grasses to make craft products; consequently, this has produced additional income for the villagers.

Presently, there is a high production competition among the vetiver handicraft smen in Phayao, and the survey result of handicraftsmen's production illustrates that the strength is, according to the long history of bamboo interlacing as well as fabric weaving, high-value cultural products are made and the skill is in herited from generation to generation. It helps the producer in proficiency, and the products are created elaborately by using a noncomplex procedure and local materials.

The production is conducted without damaging natural resources or the environment; furthermore, there is a low expenditure in all processes. However, it still has weaknesses: firstly, it is time-consuming in production processes which is disadvantageous to commercial competition. Secondly, the significant lack of knowledge as 
well as creative ideas of the handicraftsmen brings about a lack of ability to create products which have a modern style and a utility that meets the customers' demand. This also causes other serious problems: such as production imitation among the producers, incapacity to register the five-star-OTOP-product classification, which results in an inability to trade at an international level; the limited channels of distribution; and an inability to add value to the product, which effectuates the making of more money in families or communities. As aforementioned, the prompt resolution of these cases is required; in another word, the handicraftsmen want to develop the product in order to meet market expectations continuously and sustainably.

There are many methods of vetiver handcraft product development nowadays, such as the form and figure development in order to suit a utility, technique and process development, product quality development, and also vetiver fiber development for textiles. These innovations have to use manufacturing technology; therefore, most benefits become the property of manufacturers. On the other hand, the handicraftsmen, who previously produced the product by hand, unavoidably miss out on the opportunity. To resolve this, it is essential to have a campaign emphasizing the eco-friendly and natural-material applications or products which can reduce the global warming effect. Additionally, the research considered the vetiver handicraft product development process, which contains the content of original capital in both social capital and cultural capital that can bring about further development as well as creating a standardized home decorative product in which social context and cultural identity in different areas has more value and worth. This can result in higher earnings for a better life, as well as a sustainable environment.

\section{Research Objectives}

(1) To create a vetiver seat cushion for decorating a house.

(2) To evaluate the received home decorative vetiver seat cushion.

\section{Research Conceptual Framework}

Assuming that taking the cultural capital to develop the vetiver sitting cushion pads will have a quality in accordance with an OTOP standard for vetiver handcrafts.

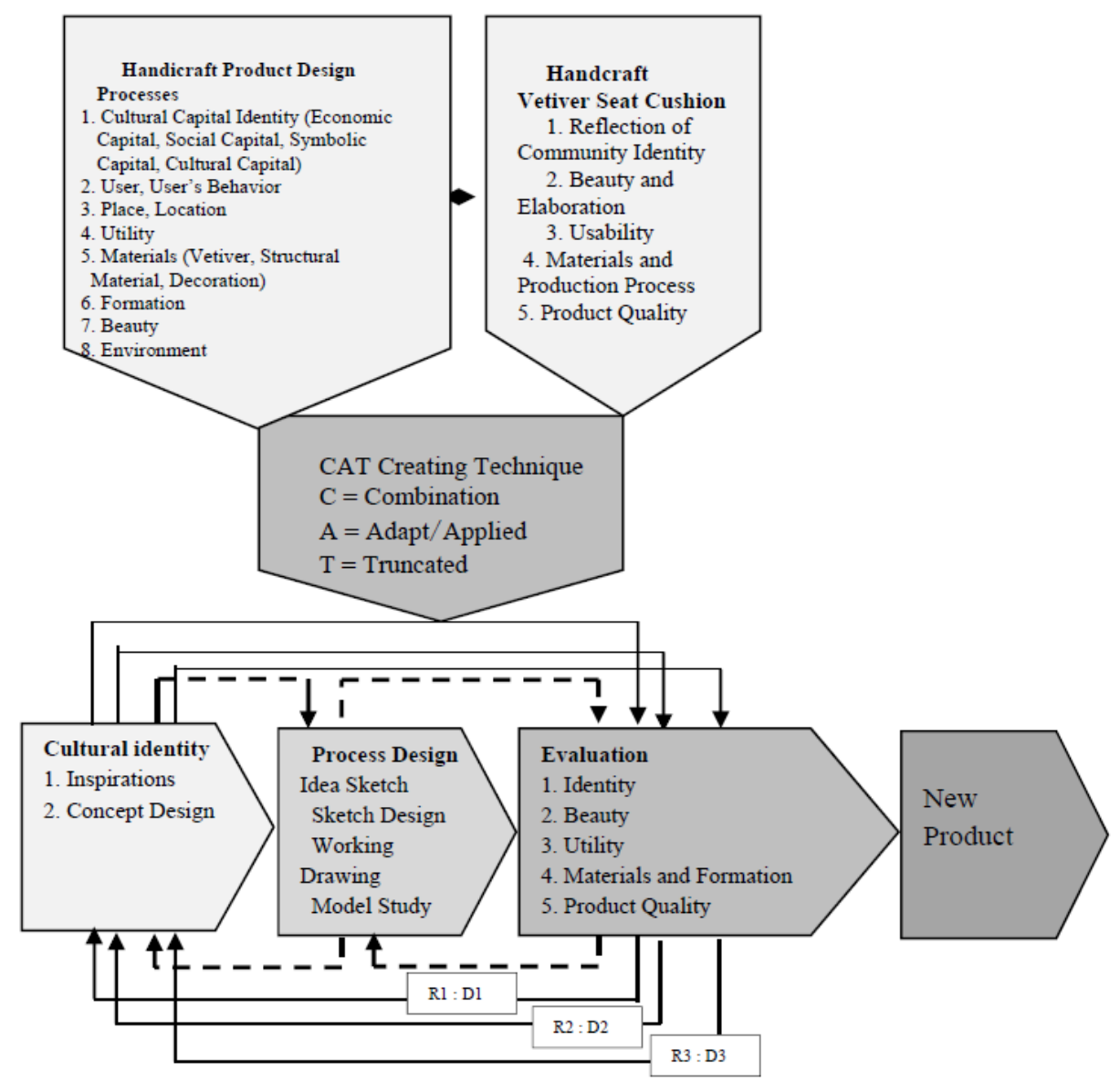

Figure 1. Conceptual framework. 


\section{Research Methodology}

This study was research and development cooperating with the community in an action research using a systematic research process in order to create new ideas or alternative procedures in vetiver product development.

\subsection{Scope of Research}

The delimitation of the study included:

Stage 1: Area Scope and sampling: the area scope was in Phayao province, and only vetiver handicraftsmen who continuously in merited the family business more than 10 years were targeted. The research used purposive sampling method; the population is segmented into 3 groups which there are 30 people per group.

Stage2: The 3 product design experts, whom specialized in vetiver products, were skillful, and had knowledge about product design at least 10 years, were selected.

Stage 3: Consumer sampling: the target audiences that the researcher selected were people and travelers in Bangkok, which totaled 100 people by using convenience sampling at Chatuchak Weekend market.

Stage 4: Design limitation: the researcher created a set of seat cushion pads for home decorating.

\subsection{Research Instrument}

Stage 1: Using an in-depth interview technique, as well as a participant observation, to gain information from the vetiver handicraftsmen in Phayao about management, material preparation, transformation, problems of original product and design development.

Stage 2: Participating in the vetiver handcraft product development by cooperating with the vetiver handicraftsmen in Phayao province both before and after developing the vetiver product model to the producers and the specialists. Additionally, the assessments were designed 2 times by using questionnaires with the product model in order to evaluate: the reflection of the product towards cultural identity of the vetiver community in Phayao, the suitability and beauty, the appropriateness of utility as well as the properness of materials and production process.

Stage 3: Using questionnaires to assess user's satisfaction through the product model on: the reflection of the product towards cultural identity of the vetiver community in Phayao, the suitability and beauty, the appropriateness of utility, the properness of materials and production process (after reformation) as well as the product quality.

\section{Data Collection and Data Analysis}

\section{Research Step 1: Preparation and Collecting Data}

(1) Site surveys were conducted, a meeting was held to explain the activity description, preparation, and bring understanding correspondingly in order to develop the handicraft sitting cushion.

(2) The product model categories were learned and investigated, and information was gathered from the target group by using interviews, structured interviews and observation to study problems, resolution and market tendencies.

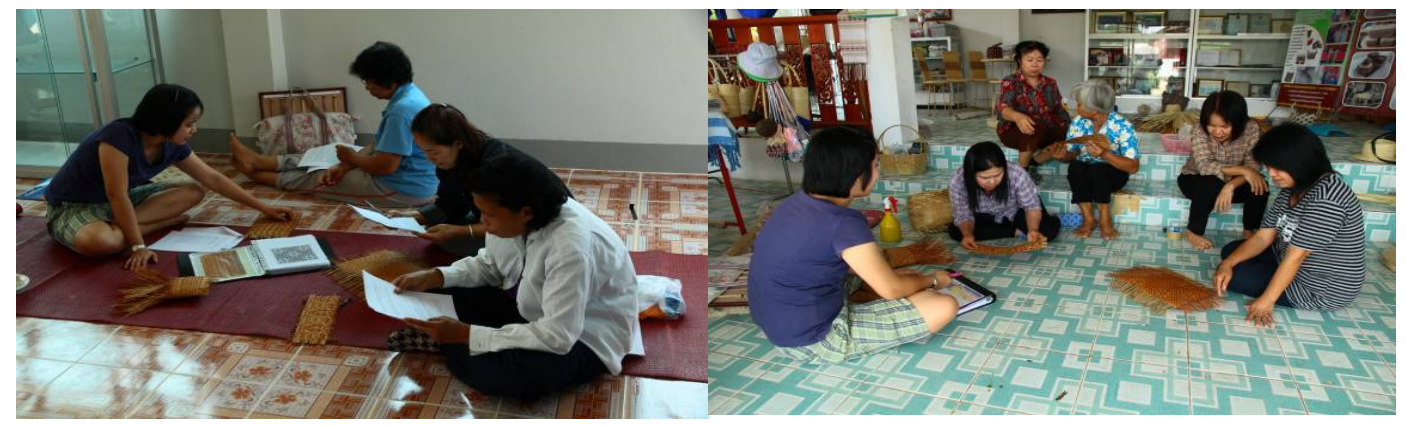

Figure 2. Bringing understanding about product design and development. 
Research Step 2: Three Archetypes of Drafting Development

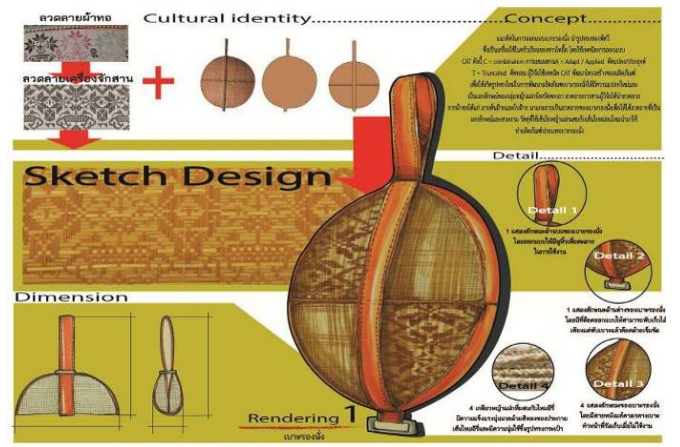

Seat Cushion Type 1: This sitting pad is inspired by the figure of a manual blower fan which is the Tai Lue stuff. The product structure is developed and reshaped in order to promote the exoticness and identity of vetiver handcraft community in Prayao. In regard to the interlacing pattern, the researcher adapts fabric patterns, such as cotton-tree pattern and cotton-leaf pattern into seat cushion pattern design to boost the unique as well as beauty. In addition, the materials used are vetiver leaf mixed with leather.

Figure 3. The design and development of the Seat Cushion Pad Type 1. Designed by Rosjana Chandhasa.

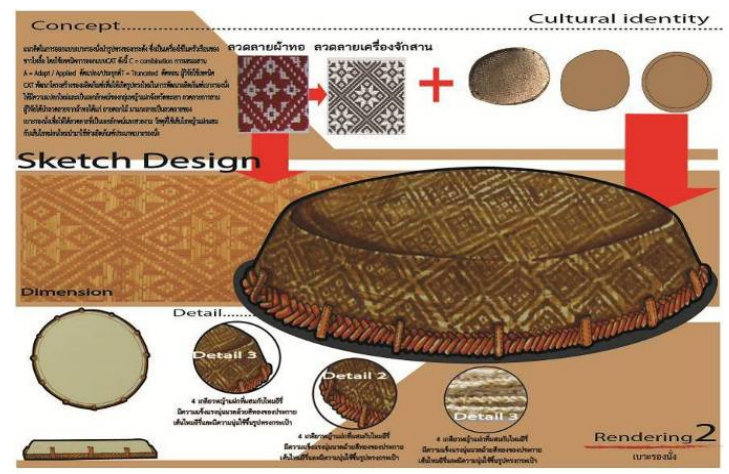

Seat Cushion Type 2: The idea of this sitting pad came from the shape of a threshing basket which was a Tai Lue item. Its structure was improved in order to create a new form. According to remaking the exoticness and identity of vetiver handcraft community in Phayao, the researcher brought the fabric pattern, which was a flower pattern, to put into seat cushion pattern design to boost the uniqueness as well as beauty, and the materials used in this recreating were vetiver leaf mixed with leather.

Figure 4. The design and development of the Seat Cushion Pad Type 2. Designed by Rosjana Chandhasa

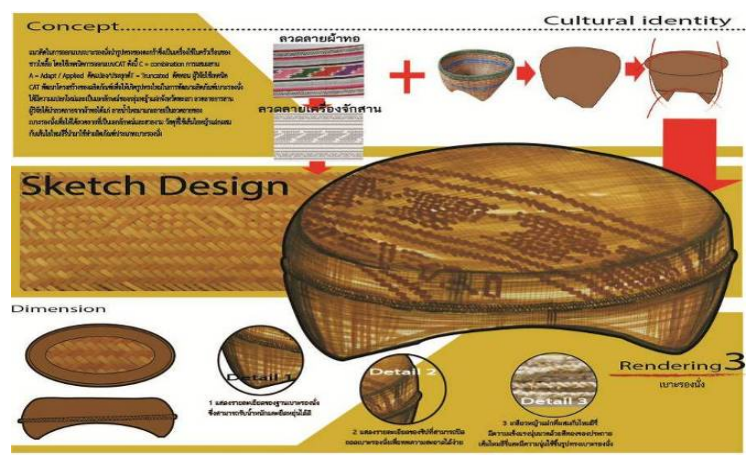

Seat Cushion Type 3: The inspiration of this sitting pad was the figure of a basket which was a Tai Lue item. Recreating the exoticness and identity of vetiver handcraft community in Phayao, the researcher adapted a fabric pattern which was a Tai Lue Ikat pattern into the interlacing pattern of seat cushion in order to highlight its uniqueness as well as beauty. The materials used in this recreating were vetiver leaf mixed with leather.

Figure 5. The design and development of the Seat Cushion Pad Type 3. Designed by Rosjana Chandhasa

Research Step 3: The Production of Three Seat Cushion Pad Models.

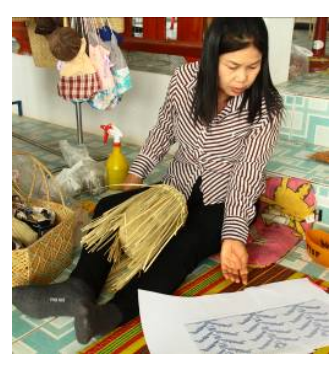

Figure 6. Interlacing the tree pattern

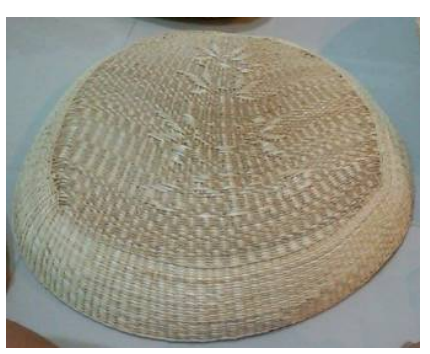

Figure 7. The finished weaving pattern before fixing with leather

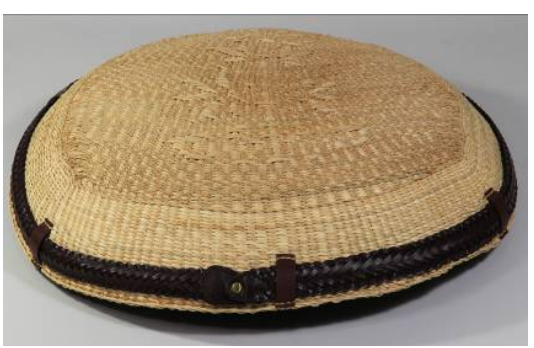

Figure 8 . The seat cushion inspired by the manual blower fan attached with leather and containing with a bag containing leftover cloth inside 


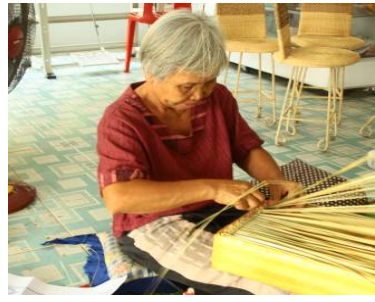

Figure 9. Interlacing the cotton pattern.

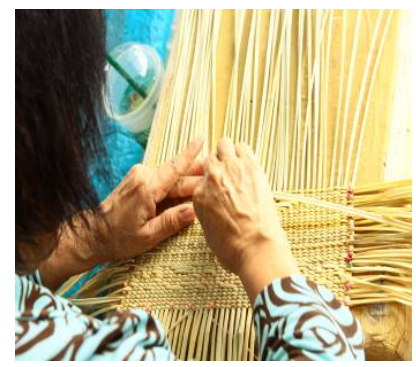

Figure 12. Interlacing the Tai Lue Ikat pattern and finishing the rim.

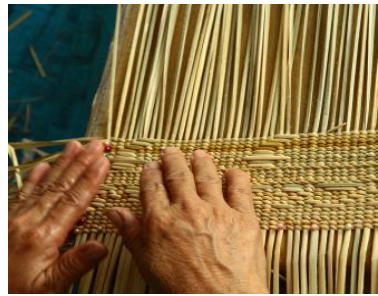

Figure 10. The pattern from the middle to rim of vetiver interlacing by following the archetype.

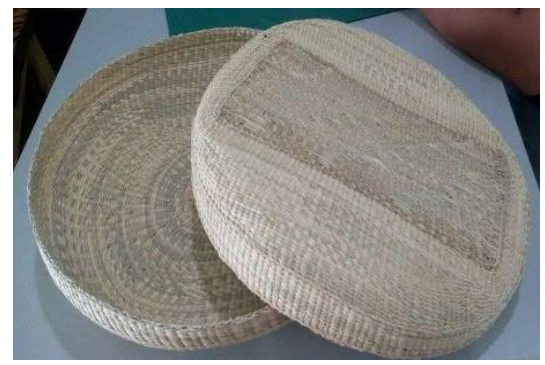

Figure 13. After interlacing and taking out from the archetype before fixing with leather.

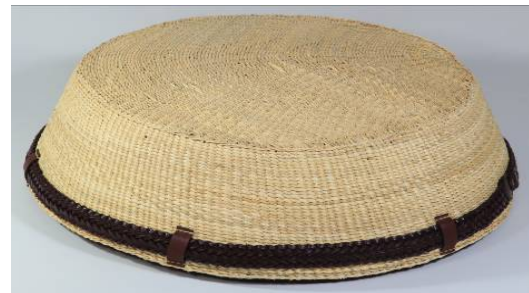

Figure 11. The seat cushion inspired by the threshing basket attaching with leather and containing with a bag containing leftover cloth inside.

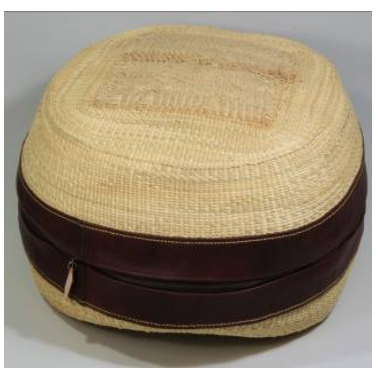

Figure 14. The seat cushion inspired by the basket attached with leather and containing a bag with the leftover cloth inside.

\section{Conclusion of Research Results}

The analysis result of the satisfaction towards the seat cushion conducted from 3 target groups (consumers, specialists and producers) are shown in Table 1:

Table1. The Analysis Result of the Satisfaction towards the Seat Cushion Conducted from 3 Target Groups

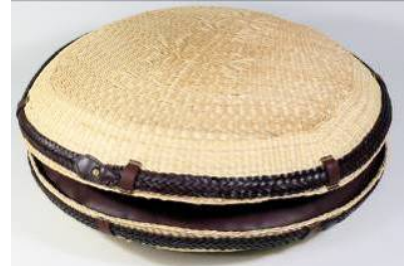

The Model of Seat Cushion Type 1

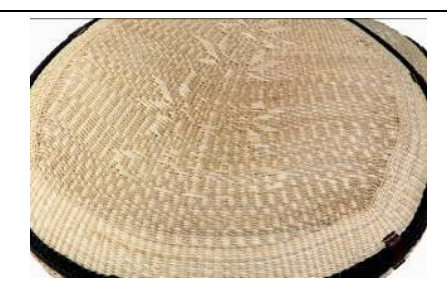

The pattern detail of Seat Cushion Type 1 (Cotton Pattern)

The researcher had to build the model different from the draft because the fold seat pad could not be sewn. If a producer forces it, the

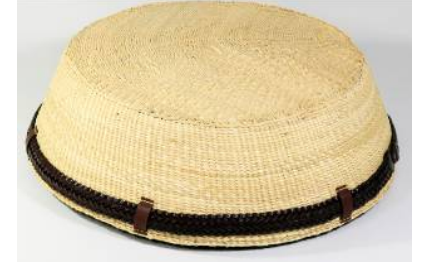

The Model of Seat Cushion Type 2

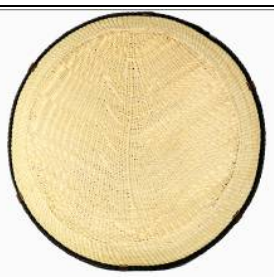

The pattern detail of Seat Cushion Type 2 (Tree Pattern)

The model could be finished which was relevant to the draft.

(Tai Lue Ikat Pattern)

The researcher had to build the model different from the draft, because the rim had to be strengthened by adding leather to be attached between two pieces. This could also 
interlaced vetiver will be broken and loose. Therefore, the seat pad is designed in the form of a two-piece attachment. make the sitting pad stronger. Regarding the pattern, the producer could not weave the Ikat pattern into all of interlacing, so the producer weaved the Tai Lue Ikat Pattern in the rectangle shape only in the middle.

\begin{tabular}{|c|c|c|c|c|c|c|c|c|c|}
\hline \multirow[t]{2}{*}{ Lists of Seat Cushion } & \multicolumn{2}{|c|}{$\begin{array}{c}\text { Consumers } \\
\mathrm{N} 1=\mathbf{1 0 0}\end{array}$} & \multicolumn{2}{|c|}{$\begin{array}{c}\text { Specialists } \\
\text { N2 }=3\end{array}$} & \multicolumn{2}{|c|}{$\begin{array}{l}\text { Producers } \\
\qquad \mathbf{N}=\mathbf{3 0}\end{array}$} & \multicolumn{2}{|c|}{$\begin{array}{c}\text { Total } \\
\mathrm{N} 1+\mathrm{N} 2+\mathrm{N} 3 / 3\end{array}$} & \multirow[t]{2}{*}{$\begin{array}{c}\text { Level of } \\
\text { Satisfaction }\end{array}$} \\
\hline & Mean & SD. & Mean & SD. & Mean & SD. & Mean & SD. & \\
\hline Seat Cushion Type 1 & 3.22 & 0.87 & 4.34 & 0.73 & 4.34 & 0.60 & 3.96 & 0.73 & High \\
\hline Seat Cushion Type 2 & 3.17 & 0.88 & 4.26 & 0.55 & 4.26 & 0.46 & 3.89 & 0.69 & High \\
\hline Seat Cushion Type 3 & 3.27 & 0.89 & 4.42 & 0.60 & 4.42 & 0.50 & 4.03 & 0.66 & High \\
\hline
\end{tabular}

According to the Table 1, the three models of sitting cushions were given to the producers. In conclusion, the first analysis result of satisfaction towards the seat cushion from the 3 groups (consumers, specialists and producers) elucidates that all target groups were most interested in the seat cushion type 3 , as evidenced by the high average at 4.03, and the suggestions for the further study (second study) include:

1. The position of Tai Lue Ikat Pattern should be developed in order to accentuate and beautify the pattern.

2. As a leather rim of the seat cushion is quite large; therefore, it should be separated into 2 pieces to promote utility.

3. Close study of the target groups will be advantageous to the development of seat cushions involving target groups' behavior.

In regard to the evaluation and suggestions through the first satisfaction analysis result, the researcher selected the sitting cushion type 3 to reform, in accordance with the suggestion that dividing it in two pieces will offer additional usability. The researcher adapted the sticky-rice wicker into an inspiration, and this recreated the product using the C-CAT theory.
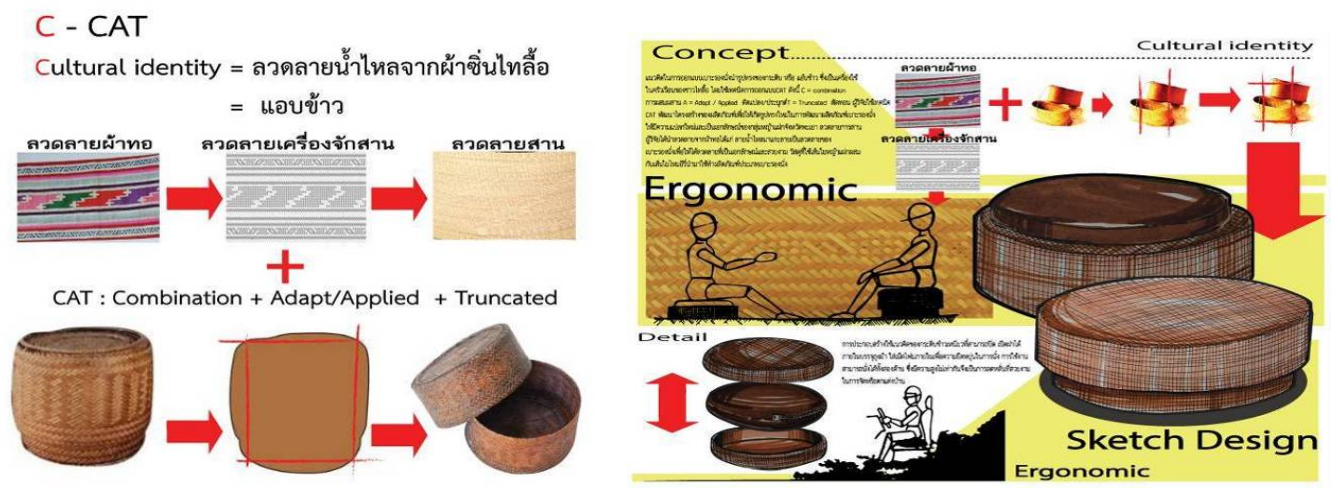

Figure 15. Refining the pattern of the seat cushion from the C-CAT theory

As observed from Figure 15 about the seat cushion idea, the researcher adapted the figure of sticky-rice wicker which is a Tai Lue item into the creation, and reformed the product structure in order to promote the exoticness and identity of the vetiver handcraft community in Phayao. In the interlacing pattern, the researcher refined the Tai Lue Ikat pattern to adapt into the sitting pad pattern designed to boost the unique as well as beauty. In addition, the materials used in producing the seat pad were vetiver leaf fiber mixed with Erisilk fiber.

The drafting archetype became the developed model in Table 2. It is noticeable that the usage of the sitting cushion inspired by sticky-rice wicker was when two pieces of the wicker were attached; it can be a drum round table, and when they are separated, they can be sitting cushions. Another side (vetiver side) can be used as a low tea table. 
Table 2. The Second Design of Seat Cushion Model

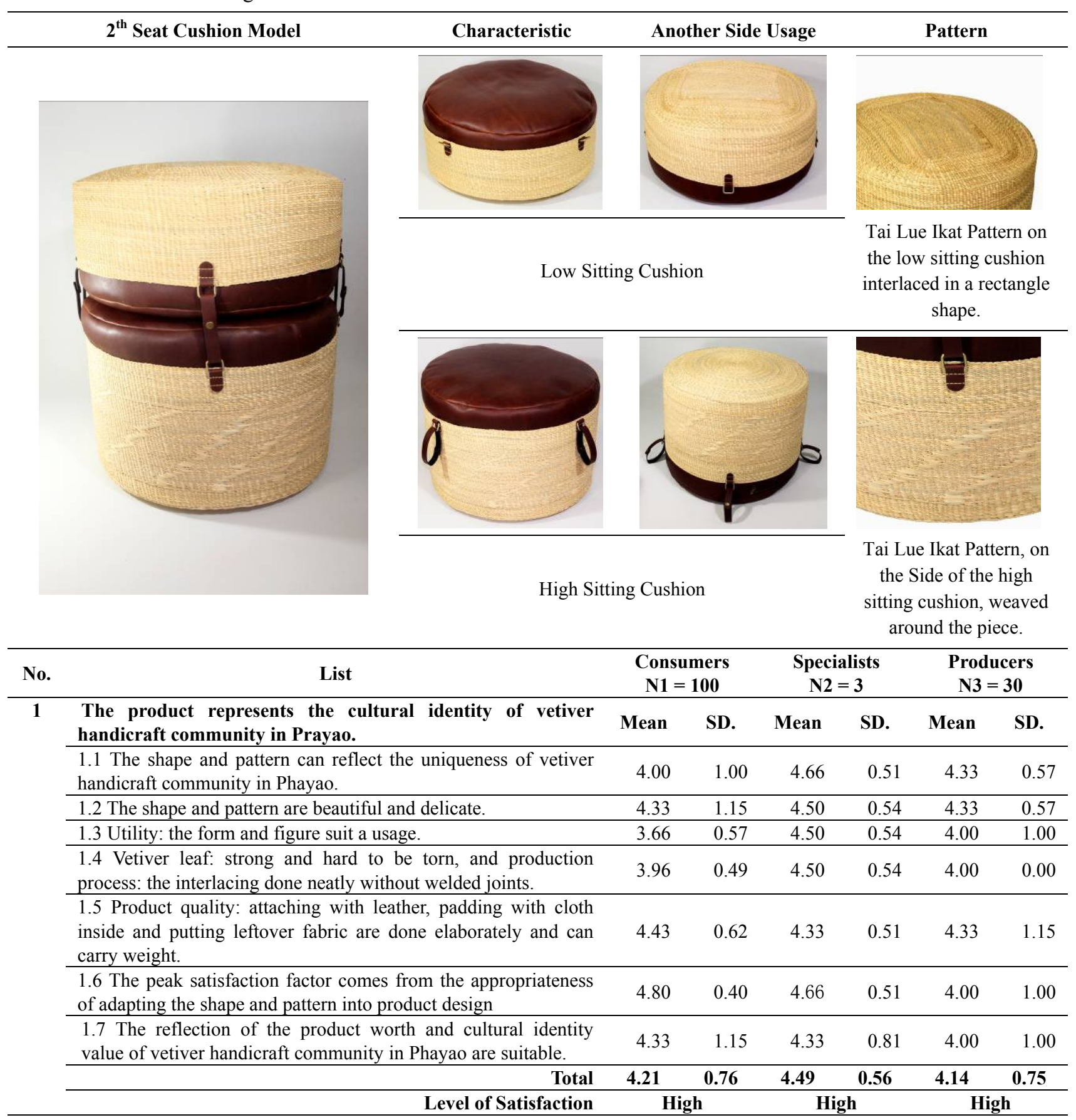

As is presented in the Table 2 about the second-design-seat-cushion assessment, the product could reflect the cultural identity of vetiver handicraft community in Phayao. Regarding the result evaluated by three target groups (consumers, specialists and producers) having the total average at 4.28, there was a high level of satisfaction which is summarized as follows:

Consumers $(\mathrm{N}=100)$ had a high level of satisfaction with a total average at 4.21. Notably, the peak satisfaction factor comes from the appropriateness of adapting the shape and pattern into product design having a high level of appropriateness with 4.80 .

Specialists $(\mathrm{N}=3)$ had a high level of satisfaction with total average at 4.49 . In addition, the highest satisfaction factors were the shape and pattern can reflect the uniqueness of vetiver handicraft community in Phayao and the appropriateness of adapting the shape and pattern into product design had the highest level of appropriateness with 4.66 . 
Producers $(\mathrm{N}=30)$ had a high level of satisfaction with total average at 4.14. Noticeably, the shape and pattern can reflect the uniqueness of vetiver handicraft community in Phayao, the exoticness is suitable for the product design and the ability to value the product were on the top of all satisfaction factors having a high level of appropriateness with 4.33 .

Table 3. The Second-Design-Seat-Cushion Assessment in Proper and Beauty Evaluated by Three Target Groups (Consumers, Specialists and Producers)

\begin{tabular}{|c|c|c|c|c|c|c|c|}
\hline \multirow{2}{*}{$\begin{array}{l}\text { No. } \\
2\end{array}$} & \multirow{2}{*}{$\begin{array}{l}\text { List } \\
\text { Properness and Beauty }\end{array}$} & \multicolumn{2}{|c|}{$\begin{array}{c}\text { Consumers } \\
\mathrm{N} 1=100\end{array}$} & \multicolumn{2}{|c|}{$\begin{array}{l}\text { Specialists } \\
\mathrm{N} 2=3\end{array}$} & \multicolumn{2}{|c|}{$\begin{array}{c}\text { Producers } \\
\text { N3 }=30\end{array}$} \\
\hline & & Mean & SD. & Mean & SD. & Mean & SD. \\
\hline & 2.1 The shape and pattern suit the beauty in product design. & 4.66 & 0.57 & 5.00 & 0.00 & 4.66 & 0.57 \\
\hline & $\begin{array}{l}2.2 \text { Interlacing pattern has an appropriate and beautiful } \\
\text { composition. }\end{array}$ & 3.83 & 1.16 & 4.66 & 0.57 & 4.33 & 0.57 \\
\hline & $\begin{array}{l}2.3 \text { The aesthetic of pattern and shape implies unique } \\
\text { characteristic of the vetiver handicraft community in Phayao. }\end{array}$ & 4.46 & 0.75 & 5.00 & 0.00 & 4.66 & 0.57 \\
\hline & 2.4 The pattern is beautiful and suits the product. & 4.00 & 0.89 & 4.00 & 0.00 & 4.00 & 0.00 \\
\hline & 2.5 The beauty of materials & 4.33 & 0.57 & 5.00 & 0.00 & 4.66 & 0.57 \\
\hline & 2.6 The overview of the product suits the beauty & 4.00 & 0.00 & 4.66 & 0.57 & 4.33 & 0.57 \\
\hline & Total & 4.21 & 0.65 & 4.72 & 0.19 & 4.44 & 0.47 \\
\hline & Level of Satisfaction & \multicolumn{2}{|c|}{ High } & \multicolumn{2}{|c|}{ Highest } & \multicolumn{2}{|c|}{ High } \\
\hline
\end{tabular}

Table 3 elucidates the second-design-seat-cushion assessment on appropriateness and beauty evaluated by three target groups (consumers, specialists and producers) having the total average at 4.45 , and there was a high level of satisfaction in the list 2.4 that the pattern was beautiful and suited the product. All target groups express satisfaction coherently in the high level with the average at 4.00, and can be summarized as follows:

Consumers $(\mathrm{N}=100)$ had a high level of satisfaction with total average at 4.21 . It shows that the first rank comes from the shape and pattern suit the beauty in product design which had the highest level of appropriateness with 4.66 .

Specialists $(\mathrm{N}=3)$ had the highest level of satisfaction with total average at 4.72 , and it was found that the top rank are the shape and pattern suit the beauty in product design, the ability to represent the unique characteristic of the vetiver handicraft community in Phayao, and the beauty of materials having the highest level of apropos relatedness with 5.00 .

Producers $(\mathrm{N}=30)$ had a high level of satisfaction with total average at 4.44 . As was observed, the shape and pattern suit the beauty in product design, the ability to represent the unique characteristic of the vetiver handicraft community in Phayao, and the beauty of materials hit the top rank which having a high level of appropriateness with 4.66 .

Table 4. The Second-Design-Seat-Cushion Assessment in Suitability of Physical Utility and Appropriateness of Materials as well as Production Process Evaluated by Three Target Groups (Consumers, Specialists and Producers)

\begin{tabular}{|c|c|c|c|c|c|c|c|c|}
\hline \multirow{2}{*}{$\begin{array}{c}\text { No. } \\
3\end{array}$} & \multirow{2}{*}{$\begin{array}{r}\text { List } \\
\text { tility }\end{array}$} & & \multicolumn{2}{|c|}{$\begin{array}{c}\text { Consumers } \\
\mathrm{N} 1=\mathbf{1 0 0}\end{array}$} & \multicolumn{2}{|c|}{$\begin{array}{c}\text { Specialists } \\
\mathrm{N} 2=3\end{array}$} & \multicolumn{2}{|c|}{$\begin{array}{c}\text { Producers } \\
\text { N3 }=\mathbf{3 0}\end{array}$} \\
\hline & & & Mean & SD. & Mean & SD. & Mean & SD. \\
\hline & 3.1 Suitability of convenience in usage & & 4.53 & 0.60 & 4.66 & 0.57 & 4.51 & 0.66 \\
\hline & 3.2 Propriety according to user's physiology & & 4.67 & 0.58 & 4.66 & 0.57 & 4.61 & 0.60 \\
\hline & 3.3 Suitability of security in usability & & 4.75 & 0.47 & 4.00 & 0.00 & 4.64 & 0.56 \\
\hline & 3.4 Suitability of maintenance and cleaning & & 4.46 & 0.75 & 4.33 & 0.57 & 4.66 & 0.55 \\
\hline & 3.5 Suability of strength & & 4.65 & 0.55 & 4.66 & 0.57 & 4.60 & 0.65 \\
\hline & & Total & 4.61 & 0.59 & 4.46 & 0.45 & 4.60 & 0.60 \\
\hline
\end{tabular}




\begin{tabular}{llrrrrrr}
\hline 4 & Appropriateness of materials and production process & Mean & SD. & Mean & SD. & Mean & SD. \\
\cline { 2 - 7 } & 4.1 Appropriateness of materials in production procedures & 4.16 & 0.98 & 4.00 & 0.89 & 4.16 & 0.75 \\
\hline $\begin{array}{l}\text { 4.2 Production assimilation is operated suitably. } \\
\text { 4.3 Is it suitable if vetiver fiber is mixed with other fibers? }\end{array}$ & 4.11 & 0.88 & 4.16 & 0.75 & 4.66 & 0.57 \\
\hline 4.4 The material used is strong & 4.44 & 0.66 & 3.50 & 1.51 & 5.00 & 0.00 \\
\hline 4.5 The material is exotic and easy to produce & 5.00 & 0.00 & 4.00 & 0.89 & 4.16 & 0.75 \\
\hline & Tevel of Satisfaction & $\mathbf{4 . 4 4}$ & $\mathbf{0 . 6 4}$ & $\mathbf{3 . 8 6}$ & $\mathbf{1 . 0 5}$ & $\mathbf{4 . 3 9}$ & $\mathbf{0 . 4 1}$ \\
\hline
\end{tabular}

According to the second-design-seat-cushion assessment, evaluated by three target groups (consumers, specialists and producers), on the suitability of physical utility had a total average at 4.55 exhibiting the highest level of satisfaction; whereas, the appropriateness of materials and production process had a total average at 4.23 which was a high level of satisfaction.

\section{Discussion of Research Result}

The research result demonstrates that investigating the community identity displayed by original hand-made basketries which can be reformed into a sitting cushion pad as well as the pattern implied a community cultural capital which could be adapted in vetiver interlacing, such as the ikat pattern, cotton pattern, and tree or flower pattern. Furthermore, Jongchansittho, P. (2014:2). Claimed that the handicraft emphasized the making of things by hand as well as using local materials. It was valuable in both aesthetics and utility; moreover, it had a different form in each area which had to be painstakingly made. Additionally, it could define the living of local people in the particular place, and the handcraft could be classified by its characteristics, such as categorizing according to the use of materials: wooden craft, metal craft, categorizing according to the production process: weaving or interlacing, and distinguishing by physical format: textile or pottery. These creations were all built by the people called "handicraftsmen," who had knowledge, and skills, which were descended from an ancestor to another generation to the next in order to continue the indigenous wisdom. The native handicraftsman was acclaimed as the "creator" as well as the "preceptor" simultaneously. Likewise, transforming the vetiver fiber by twisting with other materials in production could be elevated or reduced by considering the size of product; other fibers may be woven with the vetiver fiber by braiding or Macramé stringing which has to use the proficiency in production and material selection of the handicraft, which relates to Janyatam, J., \& Sikka, P. (2012:103). The research result exhibited that the most natural materials are fragile if they are folded or bent. Thus, the fibers should be transformed by roving or twining as a rope or braid before making a product. Roving or twining in to a rope form helps the fibers to be stronger, and it can also be formed easier. Consequently, the product can be made beautifully. The aforementioned also involved with Laowattanaphong, S. \& Smanchat, S. (2012: 231), who studied Musa genus fiber, and found that stranding the Musa genus fiber with hemp fiber made it stronger having the highest hardness test at 678.71 N (Newtons). The stranded fiber was used as a material in furniture production by weaving it in the matt-weave pattern in order to show the beautifulness of both fibers; moreover, the strong stranded fiber can be utilized in producing other products carrying weight effectively. In accordance with Soodsang, N. (2016: 179). concepts gained from this research can be applied to wood and can be used for larger composition and dimension, more natural, increased natural adaptive technologies, mirroring the world in need of sustainment and relaxation from chaos. However, furniture design work should also reflect the special need of elderly people such as for the floor, rounded table corners, strong sofas, light-weight furniture in moderate size to be movable by the elderly people themselves, independent of others. The growth of the furniture and accessories market also depends on other factors such as investment on various projects by the government sector, the government's policy to increase economic activity, the trust of the private sector of the government policy, real estate, condominium and townhome projects being launched, all are key elements in the development of different types of furniture designs. According to Mekhum,W. (2016). Has said Thailand with special emphasis on product quality, environmental protection and workplace safety. Results of the OTOP manufacturers' survey were interpreted by means of statistical analysis to show how quality and safety are interrelated in the OTOP context. Author's recommendations are provided concerning further development of OTOP manufacturing and local economies as such with the emphasis on employees' protection and higher standards guaranteed.

The study of the vetiver seat cushion development encourages the consumers to reduce using wooden furniture, since it causes deforestation, which harms the environment, as well as evokes further disadvantages later. Over 
and above, it urges the elderly together to do activities, which can lessen their depression and anxious condition.

\section{Suggestions}

1) According to agricultural extensions in growing vetiver grass in order to use in handicrafts, adequate numbers of vetiver leaf in producing products should be studied more. If the quantity of vetiver leaf is deficient, the campaign of growing more vetiver should be promoted to respond the demand in further development.

2) In adapting the vetiver fiber into the textile industry, the research result of vetiver study reveals that the qualifications of vetiver fiber, such as the fineness, hardness and flexibility are almost similar to the plant fibers are used in fabric weaving. Hence, adapting the nipa-palm-leaf fiber into other plant fibers which are able to be reeled as a thread to innovate the new type of fabric in the textile industry should be studied.

3) Regarding the vetiver transforming process in textile industry, industrial production in order to acquire the new materials in producing fabric as well as further develop the fabric to be a home decoration and clothes should be studied.

\section{Acknowledgment}

This research was supported by Suan Sunandha Rajabhat University.

\section{References}

Janyatam, J., \& Sikka, P. (2012). The Development of Nipa Palm Fiber for Use in Product Design. Academic Architecture Journals Naresuan, 3(1), 94-104. http://archmis.arch.nu.ac.th/arch_ajnu/journal/article_file/article_2012_39.pdf

Jongchansittho, P. (2014). Northern Thai Style Hairpin: The Local Wisdom of a Hairpin Maker. Institute of Culture and Arts Journal Srinakharinwirot University, 16(1), 1-15. http://www.tci-thaijo.org/index.php/jica/article/view/30521/27110

J Booth, D. \& ArdikaAdinata, N. (2003). Vetiver Grass: A Key to Sustainable Development on Bali. Conference Indonesia:eastbalipovertyproject.org. https://vetiverindonesia.files.wordpress.com/2012/01/article_pdf.pdf

Laowattanaphong, S., \& Smanchat, S. (2012). Analytical Study of Fibers from Banana Trees in Northern Area to Use in Product Design. Academic and Research Journals Rajamangala University of Technology Phra Nakho, 6(1), 266-233. http://dx.doi.org/10.14456/jrmutp.2012.16

Chandhasa, R. (2011). Vetiver: Handicraft Product on the Basis of Sufficiency Economy. Bangkok: Dewitt Press

Chomchalow, N. (2011). Vetiver Research, Development and Applications in Thailand. AU J.T. 14(4): 268-274. Bangkok: International Conference on Vetiver of Thailand. http://www.aulibrary.au.edu/multim1/ABAC_Pub/Au-Journal-of-Technology/v3-n1-4.pdf

Soodsang, N. (2016). Straw Rope Furniture Design by Macram Techniques for Housing Decorations. Asian Social Science, 12(12), 173-180. http://www.ccsenet.org/journal/index.php/ass/article/view/63170/34462

Mekhum, W. (2016). Eco-Technologies and Product Quality in OTOP 2 Production: Nonthaburi Province Case Study. Aktual'ni Problemy Ekonomiky= Actual Problems in Economics, 181, 256. $\mathrm{http} / / /$ search.proquest.com/openview/6ee4b371897a05c93bf314cb11a777e2/1?pq-origsite=gscholar\&cbl=2 035679

Tassanapilom, S. (n.d.) Research Reports of Vetiver Handcraft Production Techniques. Department of Household Industry Promotion: Family Industry Promotion Section, Department of Family and Handicraft Industry Promotion, Department of Industry Promotion

\section{Copyrights}

Copyright for this article is retained by the author(s), with first publication rights granted to the journal.

This is an open-access article distributed under the terms and conditions of the Creative Commons Attribution license (http://creativecommons.org/licenses/by/4.0/). 